\title{
Outcomes of surgery versus chemoradiotherapy in patients with clinical or pathologic stage N3 non-small cell lung cancer
}

\author{
Vignesh Raman, MD, ${ }^{\mathrm{a}}$ Oliver K. Jawitz, MD, ${ }^{\mathrm{b}}$ Chi-Fu J. Yang, MD, ${ }^{\mathrm{b}}$ Soraya L. Voigt, MD, \\ Hanghang Wang, MD, PhD, ${ }^{a}$ Thomas A. D'Amico, MD, ${ }^{\mathrm{a}}$ David H. Harpole, MD, ${ }^{\mathrm{a}}$ and \\ Betty C. Tong, MD, MHS
}

\begin{abstract}
Background: Because surgery is rarely recommended, there is minimal literature comparing the outcomes of surgery and chemoradiation in stage N3 non-small cell lung cancer (NSCLC). We examined the outcomes of definitive chemoradiation versus multimodality therapy, including surgery, for patients with clinical and pathologic stage N3 NSCLC.
\end{abstract}

Methods: The National Cancer Database was used to identify patients with clinical stage T1 to T3 N3 M0 NSCLC and clinical stage T1 to T3 Nx M0 with pathologic stage N3 NSCLC who were treated with either definitive chemoradiation or surgery between 2004-2015. A 1:1 propensity score-matched analysis was used to compare outcomes for both treatment groups in each analysis. The primary outcome was overall survival.

Results: In 935 matched patient pairs with clinical stage N3 NSCLC, surgery was associated with worse survival (hazard ratio, 1.52 ; $95 \%$ confidence interval, 1.12$2.05)$ compared with chemoradiation at 6 months, but was associated with a significant survival benefit after 6 months (hazard ratio, 0.54; confidence interval, 0.47-0.63) in multivariable analysis. In 281 pairs of patients with pN3 NSCLC, surgery had similar survival compared with chemoradiation at 6 months (hazard ratio, $1.71 ; 95 \%$ confidence interval, 0.92-3.19), but was associated with improved survival after 6 months (hazard ratio, 0.76; 95\% confidence interval, $0.58-0.99$ ). The complete resection rate was $80 \%$ and $73 \%$ for patients with clinical stage N3 and pathologic stage N3 disease, respectively.

Conclusions: In patients with clinical or pathologic stage N3 NSCLC, surgery is associated with similar or worse short-term but improved long-term survival compared with chemoradiation. In a selected group of patients with stage N3 NSCLC, surgery may have a role in multimodal therapy. (J Thorac Cardiovasc Surg 2019;158:1680-92)

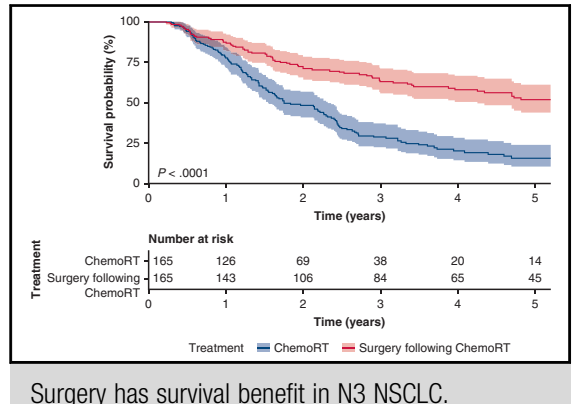

Surgery has survival benefit in N3 NSCLC.

Central Message

In patients with $\mathrm{cN} 3$ or pN3 NSCLC, surgery is associated with improved long-term survival compared with chemoradiation.

\section{Perspective}

There is minimal literature on the role of surgery for stage N3 lung cancer. Our study demonstrates that surgery is associated with a survival benefit even in persistent, pathologic N3 disease compared with chemoradiation, and suggests that surgery may have a role in multimodal therapy for patients with $\mathrm{N} 3$ NSCLC.

See Commentaries on pages 1693 and 1695.
From the a Division of Cardiovascular and Thoracic Surgery, Department of Surgery, Duke University Medical Center, Durham, NC; and ${ }^{\mathrm{b} D e p a r t m e n t ~ o f ~ C a r d i o t h o r a c i c ~}$ Surgery, Department of Surgery, Stanford University Medical Center, Stanford, Calif.

Drs Raman and Voigt were supported by a National Institutes of Health T-32 grant in surgical oncology (No. 5T32CA093245). Dr Jawitz was supported by a National Institutes of Health T-32 grant in clinical research (No. 5T32HL069749).

Read at the 99th Annual Meeting of The American Association for Thoracic Surgery, Toronto, Ontario, Canada, May 4-7, 2019.

Received for publication April 26, 2019; revisions received Aug 14, 2019; accepted for publication Aug 16, 2019; available ahead of print Oct 9, 2019.

Address for reprints: Vignesh Raman, MD, Division of Cardiovascular and Thoracic Surgery, Department of Surgery, Duke University Medical Center, 2301 Erwin Rd, Box 3443, Durham, NC 27710 (E-mail: vignesh.raman@duke.edu). $0022-5223 / \$ 36.00$

Copyright (c) 2019 by The American Association for Thoracic Surgery https://doi.org/10.1016/j.jtcvs.2019.08.033
The National Comprehensive Cancer Network and European Society of Medical Oncology guidelines recommend definitive concurrent chemoradiation as initial therapy for N3 non-small cell lung cancer (NSCLC). ${ }^{1,2}$ Surgery is not recommended for stage $\mathrm{N} 3$ disease, which has

Scanning this QR code will take you to the article title page to access supplementary information. To view the AATS Annual Meeting Webcast, see the URL next to the webcast thumbnail.

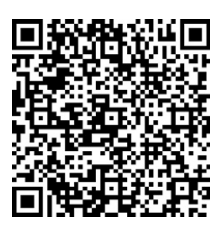




\section{Abbreviations and Acronyms \\ $\mathrm{c}=$ clinical \\ NCDB = Nation Cancer Database \\ NSCLC $=$ non-small cell lung cancer \\ $\mathrm{p} \quad=$ pathologic \\ PACIFIC $=$ Phase III, Randomised, Double-blind, \\ Placebo-controlled, Multi-centre, International Study of MEDI4736 as Sequential Therapy in Patients with Locally Advanced, Unresectable non- Small Cell Lung Cancer (Stage III) Who Have not Progressed Following Definitive, Platinum-based, Concurrent Chemoradiation Therapy}

historically been considered unresectable. However, there is minimal literature on the outcomes of surgery for these patients. Several prospective phase 2 trials of surgery following chemotherapy or chemoradiation in stage IIIB NSCLC have been published, but these are limited by small subsets of patients with $\mathrm{N} 3$ disease ranging from 7 to 32 patients, variable induction regimens, and variable study design with several excluding patients with supraclavicular node involvement. ${ }^{3-12}$ These prospective studies rarely contained subgroup analyses of patients with $\mathrm{N} 3$ disease, but showed that patients with stage IIIB lung cancer could undergo surgery with a high complete resection rate, up to $81 \%,{ }^{4}$ and with acceptable median survival ranging from $13^{8}$ to $29^{5}$ months. These prospective studies demonstrated that patients with clinical stage IIIB disease experience a high rate of pathologic nodal downstaging with induction therapy, and that recurrence was both distant and

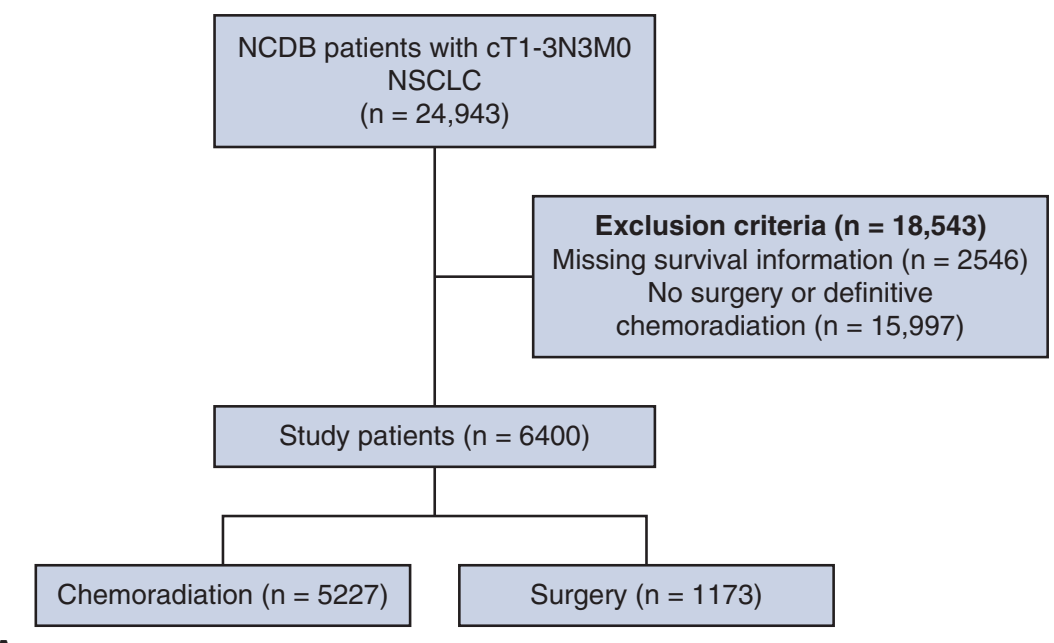

A

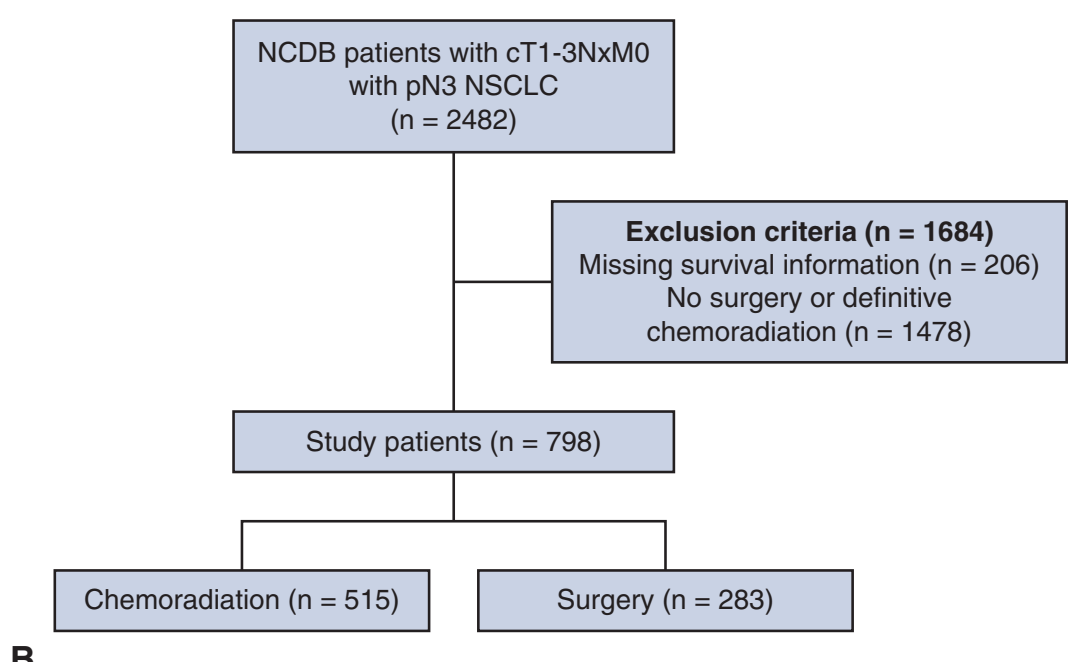

FIGURE 1. Patient selection schemes for parts of the study. A, Clinical stage (c) N3. B, Pathologic stage (p) N3. NCDB, National Cancer Database; $N S C L C$, non-small cell lung cancer. 
TABLE 1. Background characteristics of propensity score-matched patients with clinical stage N3 non-small cell lung cancer grouped by treatment

\begin{tabular}{|c|c|c|c|c|}
\hline Characteristic & $\begin{array}{l}\text { Chemoradiation } \\
\qquad(\mathbf{n}=935)\end{array}$ & $\begin{array}{l}\text { Surgery } \\
(n=935)\end{array}$ & Standard mean difference & $P$ value \\
\hline Age $(y)$ & $67(59-74)$ & $67(59-74)$ & 0.01 & .98 \\
\hline Sex (female) & $405(43)$ & $402(43)$ & 0.07 & .93 \\
\hline $\begin{array}{l}\text { Race } \\
\text { White } \\
\text { Black } \\
\text { Other }\end{array}$ & $\begin{array}{r}818(88) \\
95(10) \\
22(2)\end{array}$ & $\begin{array}{l}811(87) \\
99(11) \\
25(3)\end{array}$ & $\begin{array}{l}0.01 \\
0.02\end{array}$ & .86 \\
\hline Year of diagnosis & $2010(2007-2013)$ & $2010(2008-2012)$ & -0.007 & .80 \\
\hline $\begin{array}{l}\text { Charlson-Deyo comorbidity condition score } \\
0 \\
1 \\
2+\end{array}$ & $\begin{array}{l}526(56) \\
274(29) \\
135(14)\end{array}$ & $\begin{array}{l}519(56) \\
288(31) \\
128(14)\end{array}$ & $\begin{array}{r}0.03 \\
-0.02\end{array}$ & .75 \\
\hline $\begin{array}{l}\text { Insurance status } \\
\text { Private } \\
\text { Government } \\
\text { None }\end{array}$ & $\begin{array}{l}339(36) \\
562(60) \\
34(4)\end{array}$ & $\begin{array}{c}331(35) \\
576(62) \\
28(3)\end{array}$ & $\begin{array}{r}0.03 \\
-0.04\end{array}$ & .65 \\
\hline $\begin{array}{l}\text { Facility location } \\
\text { Metro } \\
\text { Urban } \\
\text { Rural }\end{array}$ & $\begin{array}{c}701(75) \\
184(20) \\
50(5)\end{array}$ & $\begin{array}{c}711(76) \\
169(18) \\
55(6)\end{array}$ & $\begin{array}{r}-0.04 \\
0.02\end{array}$ & .62 \\
\hline Academic center & $336(36)$ & $344(37)$ & 0.02 & .74 \\
\hline Tumor size $(\mathrm{mm})$ & $32(22-44)$ & $30(20-45)$ & -0.05 & .11 \\
\hline $\begin{array}{l}\text { Histology } \\
\text { Adenocarcinoma } \\
\text { Squamous cell carcinoma } \\
\text { Other }\end{array}$ & $\begin{array}{l}446(48) \\
353(38) \\
136(15)\end{array}$ & $\begin{array}{l}449(48) \\
358(38) \\
128(14)\end{array}$ & $\begin{array}{r}0.01 \\
-0.02\end{array}$ & .87 \\
\hline Perioperative chemotherapy & & $549(59)$ & N/A & N/A \\
\hline
\end{tabular}

Values are presented as median (interquartile range) or $\mathrm{n}(\%) . N / A$, not available.

locoregional, suggesting that there is a role for definitive local control.

There are no prospective trials and scant observational studies $^{13-15}$ comparing chemoradiation to surgery in patients with clinical stage IIIB NSCLC, including those with clinical stage (c) N3 disease. There are no studies examining the outcomes of patients with pathologic stage (p) N3 disease. The management of patients with limited N3 disease who are otherwise operable and demonstrate response to systemic therapy is not clear, and it is possible that these patients may be treated in a similar manner as operable stage IIIA (ie, N2) NSCLC with acceptable short- and long-term results. We performed a retrospective cohort study examining the outcomes of patients with $\mathrm{cN} 3$ and $\mathrm{pN} 3 \mathrm{NSCLC}$ undergoing surgery versus chemoradiation. Given the high incidence of pathologic nodal downstaging and locoregional recurrence in patients with stage IIIB NSCLC, we hypothesized that patients with cN3 NSCLC may experience a survival benefit with surgery compared with definitive chemoradiation treatment. However, we hypothesized that patients with $\mathrm{pN} 3$ disease after resection would not have a survival benefit compared with patients with $\mathrm{N} 3$ disease who received chemoradiation treatment alone.

\section{METHODS}

\section{Data Source}

The National Cancer Database (NCDB) is a joint effort of the American Cancer Society and the American College of Surgeons, and contains data collected by certified tumor registrars in 1500 centers. It includes data regarding approximately $80 \%$ of cancers diagnosed and treated annually in the United States. ${ }^{16}$

\section{Patient Selection}

This study was deemed exempt by our institutional review board. In the first part of the study, patients with American Joint Committee on Cancer Eighth Edition clinical T1 to T3 N3 M0 NSCLC were identified in the NCDB (2004-2015). Patients with missing survival, staging, or treatment information were excluded (Figure 1, A). Patients receiving chemoradiation who were not offered surgery due to poor performance status were also excluded, as were patients who received surgery more than 6 months after chemoradiation because of the possibility of a salvage procedure. In the second part of the study, patients with cT1 to cT3 Nx M0 NSCLC with pN3 disease were identified. The same exclusion criteria applied (Figure 1,B). 
TABLE 2. Multivariable Cox proportional hazards model for independent predictors of survival for propensity score-matched patients with clinical stage $\mathrm{N} 3$ non-small cell lung cancer

\begin{tabular}{|c|c|c|}
\hline Predictor & $\begin{array}{c}\text { Hazard ratio } \\
\text { (95\% Confidence } \\
\text { interval) } \\
\end{array}$ & $P$ value \\
\hline Age (per year) & $1.01(1.00-1.02)$ & $<.001$ \\
\hline Female sex (reference: Male) & $0.96(0.86-1.07)$ & .46 \\
\hline \multicolumn{3}{|l|}{ Race (reference: White) } \\
\hline Black & $1.05(0.87-1.26)$ & 61 \\
\hline Other & $1.09(0.76-1.56)$ & 64 \\
\hline \multicolumn{3}{|l|}{$\begin{array}{l}\text { Charleson-Deyo comorbidity } \\
\text { condition score (reference: } 0 \text { ) }\end{array}$} \\
\hline 1 & $1.13(1.00-1.28)$ & .05 \\
\hline $2+$ & $1.26(1.08-1.49)$ & .004 \\
\hline Year of diagnosis per year & $0.97(0.95-0.99)$ & .002 \\
\hline \multicolumn{3}{|c|}{ Insurance status (reference: Private) } \\
\hline Government & $1.09(0.94-1.25)$ & .25 \\
\hline None & $1.01(0.72-1.40)$ & .97 \\
\hline \multicolumn{3}{|c|}{ Facility location (reference: Metro) } \\
\hline Urban & $1.00(0.87-1.15)$ & 98 \\
\hline Rural & $1.21(0.96-1.52)$ & .11 \\
\hline Academic center & $0.87(0.78-0.98)$ & .02 \\
\hline Tumor size & $1.01(1.00-1.01)$ & .005 \\
\hline \multicolumn{3}{|l|}{ Histology (ref: Adenocarcinoma) } \\
\hline Squamous cell carcinoma & $0.95(0.83-1.07)$ & .38 \\
\hline Other & $1.18(1.01-1.39)$ & .04 \\
\hline \multicolumn{3}{|c|}{ Treatment (reference: Chemoradiation) } \\
\hline Surgery $(\leq 6 \mathrm{mo})$ & $1.52(1.12-2.05)$ & .006 \\
\hline Surgery (after $6 \mathrm{mo}$ ) & $0.54(0.47-0.63)$ & $<.001$ \\
\hline
\end{tabular}

Patients were grouped by treatment: surgery or definitive chemoradiation. Surgery was defined as any operation, including sublobar and lobar resections. Whereas lobar resection is considered most appropriate for patients with NSCLC, not all patients can tolerate lobectomy. To place the burden of proof on patients undergoing surgery, we included all patients who underwent lung resection regardless of type of surgery or receipt of perioperative chemotherapy or radiation to obtain the most conservative estimate of the effect of surgery on survival. We performed subgroup analyses on patients receiving lobar resection alone and those receiving multimodal therapy, including surgery. Patients who received perioperative chemotherapy or radiotherapy as well as those who received no perioperative therapy were included. The NCDB does not contain information on restaging after induction therapy. Definitive chemoradiation was defined as administration of chemotherapy and radiation of 60.0 Grey (Gy) or more, in concordance with the National Comprehensive Cancer Network guidelines. Patients who received either sequential or concurrent chemoradiation were included because not all patients can tolerate concurrent chemoradiation treatment. Although the NCDB does not explicitly code invasive mediastinal staging, a subset of patients who did not receive surgery have pathologic nodal staging recorded in addition to clinical TNM staging, suggesting that the pathologic stage for these patients reflects the findings of invasive nodal staging. Because the second part of the study focused on patients with proven N3 disease, only patients with $\mathrm{cNx}$ to $\mathrm{pN} 3$ disease receiving definitive chemoradiation were included. Pathologic nodal downstaging is defined as a lower pathologic nodal stage following surgery compared with initial clinical nodal stage. Because the NCDB does not catalog restaging after neoadjuvant therapy, any downstaging that occurred as a result of neoadjuvant therapy would only be reflected in the postoperative pathologic stage recorded.

\section{Statistical Analysis}

Background characteristics between patients in each group were compared using the Wilcoxon rank sum and Pearson $\chi^{2}$ tests for continuous and categorical variables, respectively. To minimize differences between the study groups, a propensity score-matched analysis was performed in each part of the study using patient and tumor-related variables including age, sex, race, Charlson-Deyo comorbidity condition score, year of diagnosis, insurance status, treatment at an academic center, urban or rural status, histology, and tumor size. A 1:1 nearestneighbor algorithm ${ }^{17}$ was used that utilizes a series of logistic regressions to match control and treatment groups on distance; we used a caliper of 0.15 to eliminate differences and ensure a mean standardized difference $\leq 0.1$ for each variable. ${ }^{18,19}$ We report the mean standardized differences in Tables 1 and 2. For the analysis of pN3 disease, clinical nodal status was also included in both the multivariable regression and for propensity matching.

The primary outcome was overall survival, which was evaluated using Kaplan-Meier and Cox proportional hazards estimates. In both parts of the study, the Kaplan-Meier curves intersected at about 6 to 9 months, and the proportional hazards assumption was violated (Schoenfeld residual $P<.05)$. To resolve this, the cohorts in each analysis were divided into 2 before the point of intersection (6 months) and modeled as time-varying coefficients in a single multivariable Cox model. ${ }^{20}$ The following subgroup analyses were performed: cohort limited to patients receiving neoadjuvant therapy (cN3), lobar resection ( $\mathrm{cN} 3$ and $\mathrm{pN} 3)$, a complete resection (pN3), or perioperative chemotherapy (pN3).

In survival analyses, missing data were handled with complete case analysis for each variable included in the multivariable Cox models. In other descriptive statistics such as pathologic nodal staging, the fraction of missing data is reported for each group. All statistical analysis was performed using $\mathrm{R}$ version 3.5 for Mac (R Foundation for Statistical Computing, Vienna, Austria).

\section{RESULTS \\ cN3 Disease}

A total of 6400 patients met study criteria: 5227 underwent chemoradiation treatment $(82 \%)$ and 1173 underwent surgery $(18 \%)$. Compared with chemoradiation, surgery patients had a lower T stage, were less likely to have adenocarcinoma, had more comorbidities, and were more likely to be treated at an academic medical center (Table E1). In the surgery group, 616 patients $(53 \%)$ received perioperative therapies: $209(18 \%)$ received induction chemotherapy with or without radiation and $407(37 \%)$ received adjuvant chemotherapy. The most common operation was lobectomy, followed by wedge resection, and pneumonectomy. A margin-negative (R0) resection was achieved in $80 \%$ of patients. The median survival was 20 months $(95 \%$ confidence interval $[\mathrm{CI}], 20-21$ months) for chemoradiation and 35 months (95\% CI, 32-39 months) for surgery (Figure 2, A). In a multivariable Cox model, surgery was associated with worse survival compared with chemoradiation in the first 6 months (hazard ratio [HR], 1.34; 95\% CI, $1.07-1.67 ; P=.01)$. After 6 months, there was a significant 

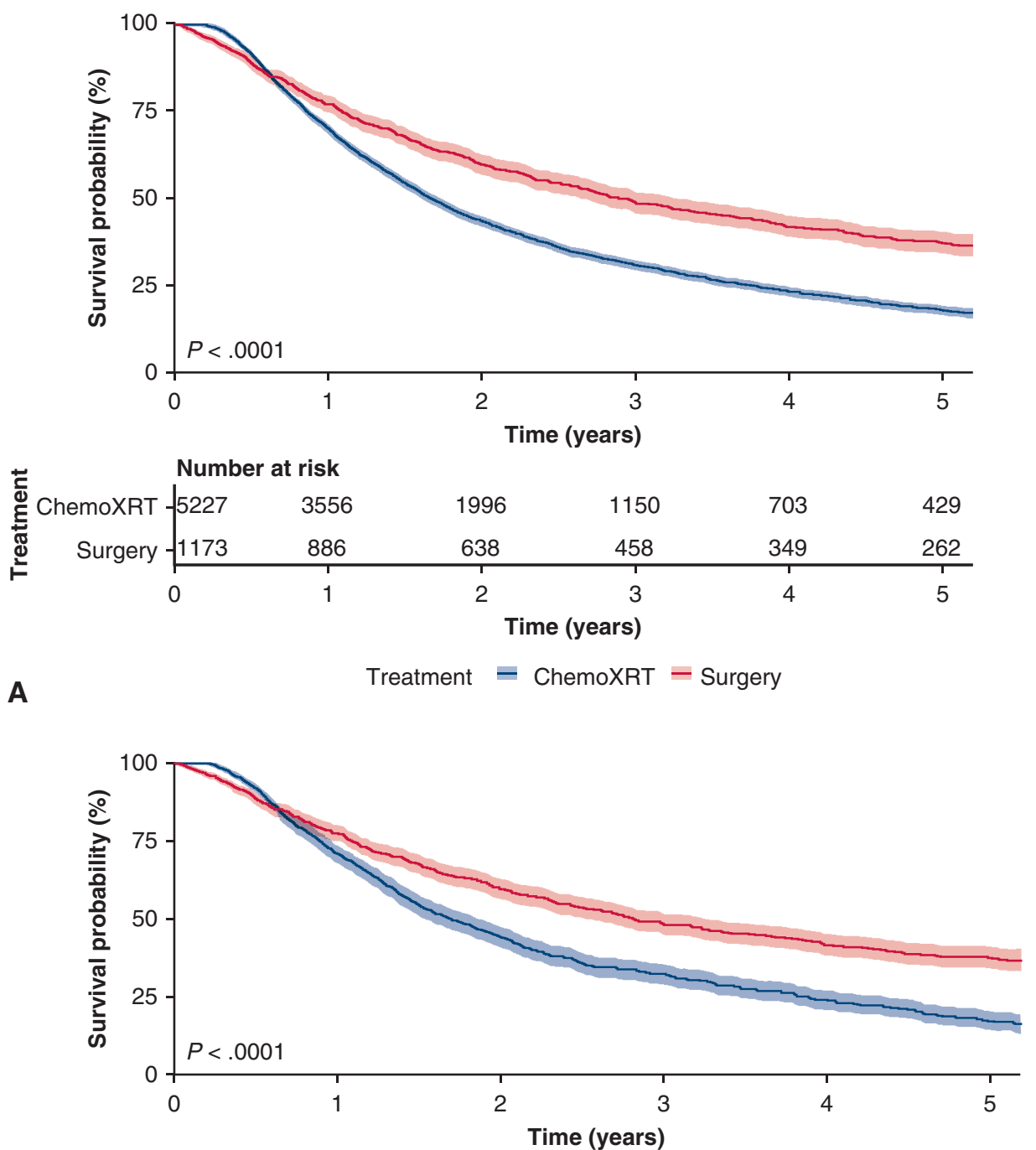

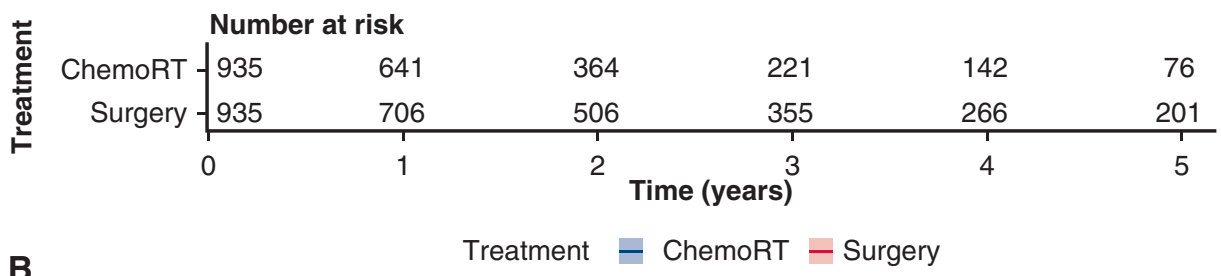

FIGURE 2. Kaplan-Meier survival curves for propensity score-matched patients with clinical stage N3 NSCLC, grouped by treatment of chemoradiation (chemoRT) versus surgery, with log-rank test reported as a $P$ value and numbers at risk for each group provided beneath the figure. The $y$-axis refers to the percentage of patients alive, and the $x$-axis refers to the time, in years, from diagnosis. A, Overall cohort. B, Propensity score-matched patients only. ChemoXRT, Chemotherapy and radiation therapy.

overall survival benefit with surgery compared with chemoradiation (HR, 0.54; 95\% CI, 0.48-0.61; $P<.001$ ). Amongst 5227 chemoradiation group patients with cN3 disease, only 550 had a pathologic nodal stage recorded ( $30 \%$ missing and 59\% pNx): $458(83 \%)$ had $\mathrm{pN} 3$ disease, 68 $(12 \%)$ had $\mathrm{pN} 2$ disease, $14(3 \%)$ had $\mathrm{pN} 1$ disease, and $10(2 \%)$ had pN0 disease. Amongst surgery group patients (6\% missing and $26 \% \mathrm{pNx}), 174(16 \%)$ had $\mathrm{pN} 3$ disease,
$133(12 \%)$ had $\mathrm{pN} 2$ disease, $109(10 \%)$ had $\mathrm{pN} 1$ disease, and $397(36 \%)$ had $\mathrm{pN0}$ disease.

A total of 935 pairs of patients were identified by 1:1 propensity score matching. Background characteristics of patients in each group are summarized in Table 1. The median survival was 20 months (95\% CI, 18-22 months) and 34 months ( $95 \%$ CI, 30-39 months) for chemoradiation and surgery group patients, respectively (Figure 2, B). In 

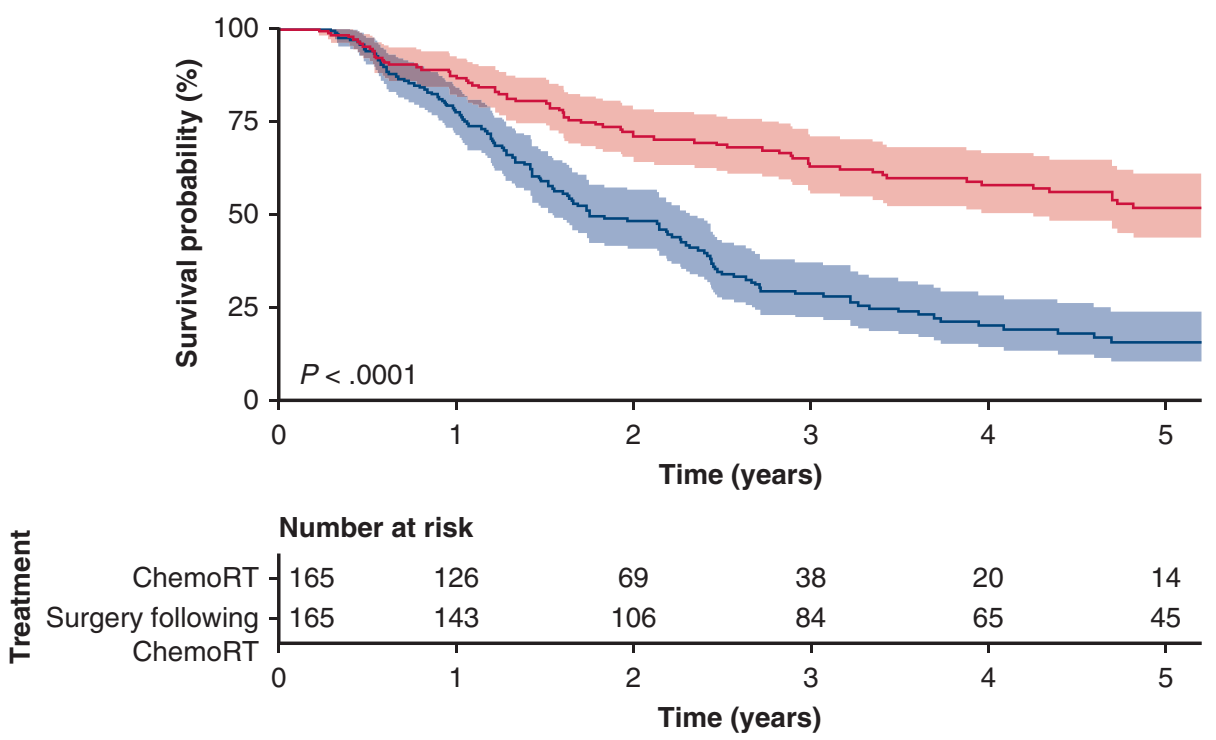

Treatment $=$ ChemoRT $=$ Surgery following ChemoRT

FIGURE 3. Kaplan-Meier survival curves for propensity score-matched patients with clinical stage N3 NSCLC, grouped by treatment of chemoradiation (chemoRT) versus surgery following induction therapy with log-rank test reported as a $P$ value and numbers at risk for each group provided beneath the figure. The $y$-axis refers to the percentage of patients alive, and the $y$-axis refers to the time, in years, from diagnosis.

multivariable analysis, surgery was associated with worse survival compared with chemoradiation within the first 6 months of diagnosis, but after 6 months, surgery was associated with a significant benefit in overall survival compared with chemoradiation (Table 2).

Only 209 patients (18\%) undergoing surgery received induction chemotherapy, suggesting that a significant fraction of patients with $\mathrm{cN} 3$ disease were downstaged by invasive nodal assessment. We therefore performed a propensity score-matched subgroup analysis of only patients receiving surgery following induction therapy, presuming these patients had pathologically demonstrated N2 or N3 disease at the time of presentation. Surgery and chemoradiation patients had a median survival of 64 months (95\% CI, 5173 months) and 21 months (95\% CI, 19-28 months), respectively. In both unadjusted (Figure 3) and adjusted analysis, patients undergoing surgery with induction therapy experienced better survival compared with those receiving chemoradiation (HR, $0.41 ; 95 \% \mathrm{CI}, 0.31-0.55 ; P<.001$ ). Of surgery patients ( $7 \%$ missing, $20 \% \mathrm{pNx}), 131(86 \%)$ had a lower pathologic $\mathrm{N}$ stage compared with initial clinical stage, with $81(53 \%)$ demonstrating $\mathrm{pN} 0$ disease.

In a separate subgroup analysis of only patients receiving a lobar resection, 556 matched pairs of patients were identified. Within the first 6 months, there was no difference in survival between surgery and chemoradiation group patients (HR, $1.03 ; 95 \% \mathrm{CI}, 0.68-2.45 ; P=.88$ ), but surgery was associated with improved survival compared chemoradiation after 6 months (HR, 0.42; 95\% CI, 0.35-0.51; $P<.001)$.

\section{pN3 Disease}

A total of 798 patients with pN3 disease met study criteria, of whom $515(65 \%)$ and $283(35 \%)$ underwent chemoradiation and surgery, respectively. The clinical nodal stage of each treatment group is summarized in Table 3. Compared with chemoradiation group patients, surgery group patients were more likely to have been diagnosed earlier, be treated in a metropolitan area, and be less likely to have adenocarcinoma (Table E2). Of surgery group patients, $184(66 \%)$ underwent perioperative chemotherapy: $31(12 \%)$ received induction chemotherapy and $153(55 \%)$ received adjuvant chemotherapy. The most common operation was lobectomy, followed by wedge resection and pneumonectomy. The $\mathrm{R} 0$ resection rate was $73 \%$. The median survival for chemoradiation group and surgery group patients was 22 months $(95 \%$ CI, 1925 months) and 24 months (95\% CI, 21-29 months), respectively (Figure $4, A$ ). In multivariable Cox regression,

TABLE 3. Clinical nodal staging of patients with pathologic stage $\mathrm{N} 3$ non-small cell lung cancer, grouped by treatment

\begin{tabular}{lcc}
\hline $\begin{array}{c}\text { Clinical N } \\
\text { stage }\end{array}$ & $\begin{array}{c}\text { Chemoradiation } \\
(\mathbf{n}=\mathbf{5 1 5})\end{array}$ & $\begin{array}{c}\text { Surgery } \\
(\mathbf{n}=\mathbf{2 8 3})\end{array}$ \\
\hline 0 & $10(2)$ & $43(15)$ \\
1 & $5(1)$ & $19(7)$ \\
2 & $28(5)$ & $39(14)$ \\
3 & $458(89)$ & $174(61)$ \\
$\mathrm{X}$ & $14(3)$ & $8(3)$ \\
\hline Values are presented as n (\%). & &
\end{tabular}



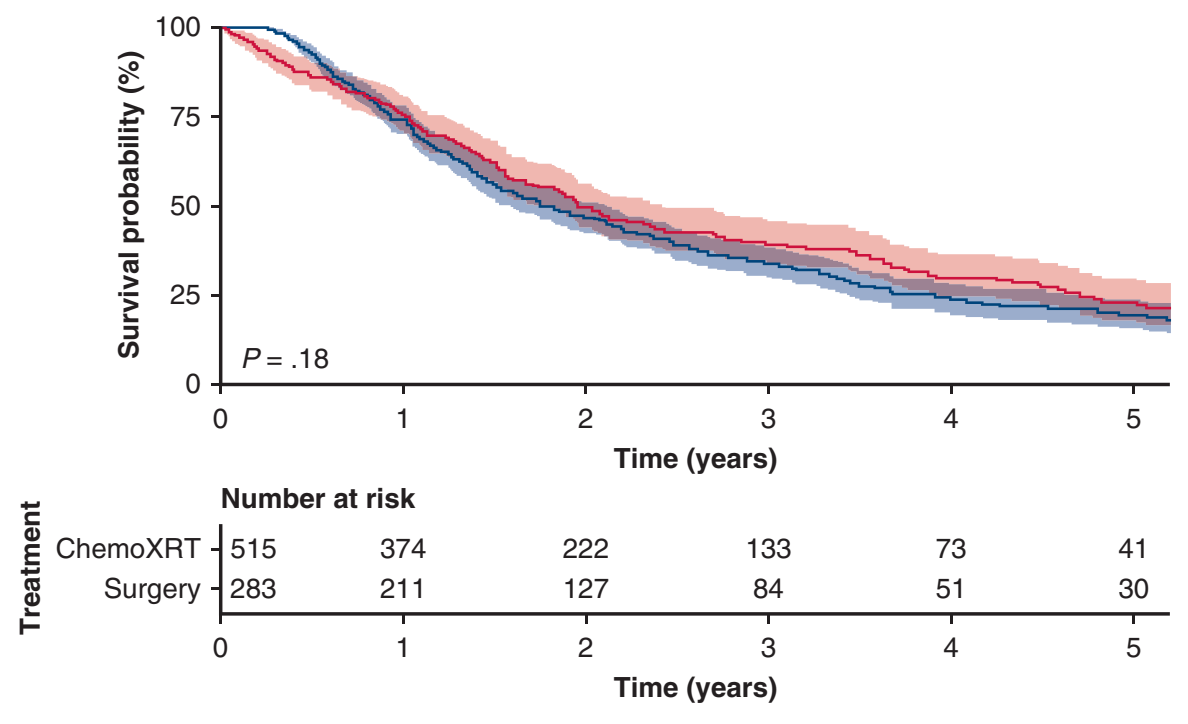

A

Treatment $=$ ChemoXRT $=$ Surgery
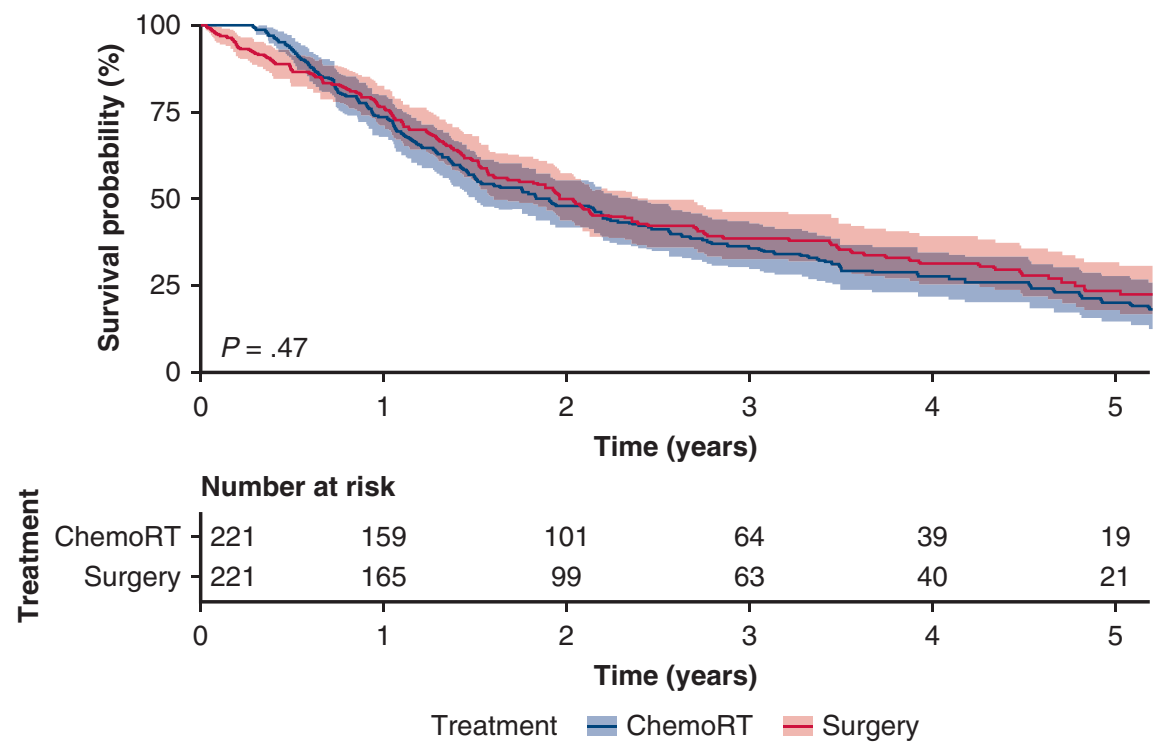

FIGURE 4. Kaplan-Meier survival curves for propensity score-matched patients with pathologic stage N3 NSCLC, grouped by treatment of chemoradiation $($ chemoRT) versus surgery with log-rank test reported as a $P$ value and numbers at risk for each group provided beneath the graph. The $y$-axis refers to the percentage of patients alive, and the $x$-axis refers to the time, in years, from diagnosis. A, Overall cohort. B, Propensity score-matched patients only. ChemoXRT, Chemotherapy and radiation therapy.

undergoing surgery was associated with worse survival compared with chemoradiation within the first 6 months (HR, 1.69; 95\% CI, 1.00-2.83; $P=.05$ ). Beyond 6 months, surgery was associated with a significant survival benefit (HR, 0.73; 95\% CI, 0.58-0.91; $P=.01$ ).

A 1:1 propensity score-matched analysis identified 221 pairs of patients with $\mathrm{pN} 3$ disease. The background characteristics of the patients are summarized in Table 4. The median survival for chemoradiation group and surgery group patients was 22 months (95\% CI, 18-28 months) and
24 months (95\% CI $19-29$ months), respectively (Figure 4, B). In multivariable regression, surgery was not associated with a significant survival benefit compared with chemoradiation within the first 6 months after diagnosis (Table 5). However, surgery was associated with a significant survival benefit after 6 months.

In a subgroup analysis of 136 matched pairs of patients who received perioperative chemotherapy, there was no difference in survival between surgery group and chemoradiation group patients (HR, $1.00 ; 95 \% \mathrm{CI}, 0.75-1.34 ; P=.99)$. 
TABLE 4. Background characteristics of propensity score-matched patients with pathologic stage N3 non-small cell lung cancer grouped by treatment

\begin{tabular}{|c|c|c|c|c|}
\hline Characteristic & $\begin{array}{l}\text { Chemoradiation } \\
\qquad(\mathrm{n}=\mathbf{2 2 1})\end{array}$ & $\begin{array}{l}\text { Surgery } \\
(n=221)\end{array}$ & Standard mean difference & $P$ value \\
\hline Age $(y)$ & $66(58-72)$ & $65(57-71)$ & -0.06 & .58 \\
\hline Female sex & $96(43)$ & $105(48)$ & -0.08 & .45 \\
\hline Race & & & & .96 \\
\hline White & $192(87)$ & $192(87)$ & & \\
\hline Black & $22(10)$ & $21(10)$ & -0.01 & \\
\hline Other & $7(3)$ & $8(4)$ & 0.02 & \\
\hline Year of diagnosis & $2010(2007-2012)$ & $2010(2007-2012)$ & -0.05 & .59 \\
\hline Charleson-Deyo comorbidity condition score & & & & .99 \\
\hline 0 & $137(62)$ & $138(62)$ & & \\
\hline 1 & $62(28)$ & $62(28)$ & 0.00 & \\
\hline $2+$ & $22(10)$ & $21(10)$ & -0.01 & \\
\hline Insurance status & & & & .96 \\
\hline Private & $89(40)$ & $88(40)$ & & \\
\hline Government & $123(56)$ & $125(57)$ & 0.02 & \\
\hline None & $9(4)$ & $8(4)$ & -0.02 & \\
\hline Facility location & & & & .24 \\
\hline Metro & $189(86)$ & $176(80)$ & & \\
\hline Urban & $25(11)$ & $33(15)$ & 0.10 & \\
\hline Rural & $7(3)$ & $12(5)$ & 0.10 & \\
\hline Academic center & $82(37)$ & $86(39)$ & 0.04 & \\
\hline Tumor size (mm) & $28(18-39)$ & $30(19-40)$ & -0.01 & .77 \\
\hline Histology & & & & .85 \\
\hline Adenocarcinoma & $141(64)$ & $139(63)$ & & .44 \\
\hline Squamous cell carcinoma & $60(27)$ & $54(24)$ & -0.06 & \\
\hline Other & $20(9)$ & $28(13)$ & 0.10 & \\
\hline Perioperative chemotherapy & N/A & $163(74)$ & N/A & N/A \\
\hline
\end{tabular}

Values are presented as median (interquartile range) or $\mathrm{n}(\%) . N / A$, not available.

In a separate analysis of patients who underwent lobar resection, there was no difference in survival between surgery group and chemoradiation group patients within 6 months (HR, 1.07; 95\% CI 0.49-2.37; $P=.86$ ), but undergoing surgery was associated with improved survival after 6 months (HR, 0.64; 95\% CI, 0.41-0.79; $P=.01$ ) in 129 matched patient pairs. In a third subgroup analysis limited to patients who received $\mathrm{R} 0$ resection, undergoing surgery was again associated with a survival benefit compared with chemoradiation treatment after 6 months in 151 matched pairs of patients (HR, 0.57; 95\% CI, 0.41-0.79; $P<.001)$.

\section{DISCUSSION}

In this propensity score-matched NCDB analysis, patients with both clinical and pathologic N3 NSCLC experienced similar short-term survival and improved long-term survival with surgery compared with definitive chemoradiation. Patients with $\mathrm{cN} 3$ disease undergoing surgery had a high rate of pathologic nodal downstaging. To our knowledge, this is the largest study examining the outcomes of patients with N3 lung cancer, and demonstrates that surgery is associated with superior long-term outcomes in a highly selected group of patients.

Our finding that patients with $\mathrm{cN} 3$ NSCLC can experience good overall survival after surgery corroborates the small amount of prospective and retrospective data in the literature. Patients undergoing surgery in our study had a median survival of 35 months, comparable to the range of 13 to 29 months reported in prospective studies. ${ }^{3,4,21}$ Similarly, patients in our study had a pathologic nodal downstaging of $51 \%$ after surgery, which is comparable to the $30 \%$ to $48 \%$ in phase 2 studies. ${ }^{3,6,9}$ Unfortunately, the prospective studies in stage IIIB NSCLC all contained only small subsets of patients with N3 disease, and generally did not examine this population separately in subgroup analyses. Similarly, a previous NCDB analysis ${ }^{13}$ of patients with clinical stage IIIB NSCLC demonstrated that multimodal therapy that included surgery was associated with a survival benefit compared with chemoradiation alone; however, 
TABLE 5. Multivariable Cox proportional hazards model for independent predictors of survival for propensity score-matched patients with pathologic stage N3 non-small cell lung cancer

\begin{tabular}{|c|c|c|}
\hline Predictor & $\begin{array}{l}\text { Hazard ratio }(95 \% \\
\text { Confidence interval) }\end{array}$ & $P$ value \\
\hline Age per year & $1.01(0.99-1.02)$ & .22 \\
\hline Female sex (reference: Male) & $0.97(0.76-1.22)$ & .77 \\
\hline \multicolumn{3}{|l|}{ Race (reference: White) } \\
\hline Black & $1.06(0.72-1.57)$ & .76 \\
\hline Other & $1.14(0.57-2.28)$ & .71 \\
\hline \multicolumn{3}{|l|}{$\begin{array}{l}\text { Charleson-Deyo comorbidity } \\
\text { condition score (reference: } 0 \text { ) }\end{array}$} \\
\hline 1 & $1.05(0.81-1.36)$ & .72 \\
\hline $2+$ & $1.46(1.00-2.14)$ & .05 \\
\hline Year of diagnosis per year & $0.94(0.90-0.98)$ & .002 \\
\hline \multicolumn{3}{|l|}{ Insurance status (reference: } \\
\hline Government & $1.01(0.74-1.38)$ & .96 \\
\hline None & $0.71(0.35-1.45)$ & .34 \\
\hline \multicolumn{3}{|l|}{$\begin{array}{l}\text { Facility location (reference: } \\
\text { Metro) }\end{array}$} \\
\hline Urban & $0.92(0.65-1.29)$ & .62 \\
\hline Rural & $0.90(0.50-1.63)$ & .74 \\
\hline Academic center & $0.86(0.68-1.09)$ & .22 \\
\hline Tumor size & $1.01(1.00-1.01)$ & .16 \\
\hline \multicolumn{3}{|l|}{ Histology (ref: } \\
\hline Squamous cell carcinoma & $1.08(0.83-1.42)$ & .56 \\
\hline Other & $0.96(0.65-1.41)$ & .84 \\
\hline \multicolumn{3}{|l|}{ Treatment (reference: } \\
\hline Surgery $(\leq 6 \mathrm{mo})$ & $1.71(0.92-3.19)$ & .09 \\
\hline Surgery (after 6 mo) & $0.76(0.58-0.99)$ & .045 \\
\hline
\end{tabular}

this study did not report a multivariable subgroup analysis of patients with $\mathrm{N} 3$ disease, only included surgery patients who received multimodal therapy, and examined patients with clinical stage IIIB disease alone. These studies did demonstrate that failure after multimodal therapy for cIIIB disease manifested as both distant metastases and local recurrence, suggesting that definitive local control in the form of surgical resection and lymphadenectomy may play a role in mitigating recurrence in $\mathrm{N} 3$ disease. In addition, the high pathologic downstaging rate in patients who underwent surgery might suggest that there is discordance between clinical and invasive nodal staging in this population, or that patients with response to induction therapy experience superior survival with surgery. The NCDB does not catalog restaging after induction therapy, so we do not know how many patients with $\mathrm{cN} 3$ disease were downstaged before or after surgery. However, only $21 \%$ of patients undergoing surgery received neoadjuvant chemotherapy in our study, suggesting that significant downstaging might occur with invasive nodal staging alone. Our study reinforces the importance of invasive nodal staging, especially as studies suggest that a minority of patients nationwide receive invasive staging with significant center variability. ${ }^{22,23}$ Further, in a subgroup analysis of cN3 patients who underwent induction therapy and surgery, we found an $87 \%$ pathologic nodal downstaging rate, suggesting that patients with good response to induction therapy were more likely to receive surgery and experience improved survival.

We then expanded our study to investigate the outcomes of patients, regardless of clinical stage, with $\mathrm{pN} 3$ disease. As expected, more than half of patients with $\mathrm{pN} 3$ disease had $\mathrm{cN} 3$ disease, with the remainder being upstaged. Prospective studies in stage III NSCLC have demonstrated that pathologic involvement of mediastinal nodes predicts mortality, ${ }^{6,9,21}$ and we hypothesized that patients with $\mathrm{pN} 3$ disease undergoing surgery or chemoradiation would experience similar survival. Our finding that mid to late survival is improved in patients undergoing surgery suggests that in selected patients with persistent $\mathrm{N} 3$ disease, surgery can offer acceptable outcomes. Indeed, 1 prospective study of stage III NSCLC found that patients with N2 and N3 disease were equally likely to have sterilization of mediastinal nodes, ${ }^{3}$ suggesting that patients with $\mathrm{N} 3$ disease may have tumor behavior more aligned with $\mathrm{N} 2$ rather than $\mathrm{T} 4$ disease, and might benefit from multimodal therapy that includes surgery.

In both parts of our study, we found that early survival, less than about 6 months, was either similar between patients undergoing surgery and chemoradiation or worse for surgery patients. Examining the survival curves (Figures 2 and 3), the curves for chemoradiation group patients remain flat early after diagnosis, whereas the curves for surgery group patients fall immediately. This suggests that there might be immortal time bias in patients receiving chemoradiation, who have to survive several weeks to months to successfully receive definitive chemoradiotherapy, whereas patients undergoing surgery shortly after diagnosis may die soon after from complications related to surgery or from comorbidities. Our time-varying Cox models adjust for this finding.

This study allows us to draw inferences on patients with N3 disease who may most benefit from surgery that can be augmented by experience from our institution. Our subgroup analysis of $\mathrm{cN} 3$ patients who received neoadjuvant therapy suggests that patients who respond well to neoadjuvant therapy may experience improved long-term survival compared with those receiving chemoradiation. In addition, our subgroup analyses on patients receiving lobar resections and margin-negative resections suggest that patients who may tolerate a lobar resection and with a high probability 


\section{Surgery vs. Chemoradiation in N3 Non-Small Cell Lung Cancer}
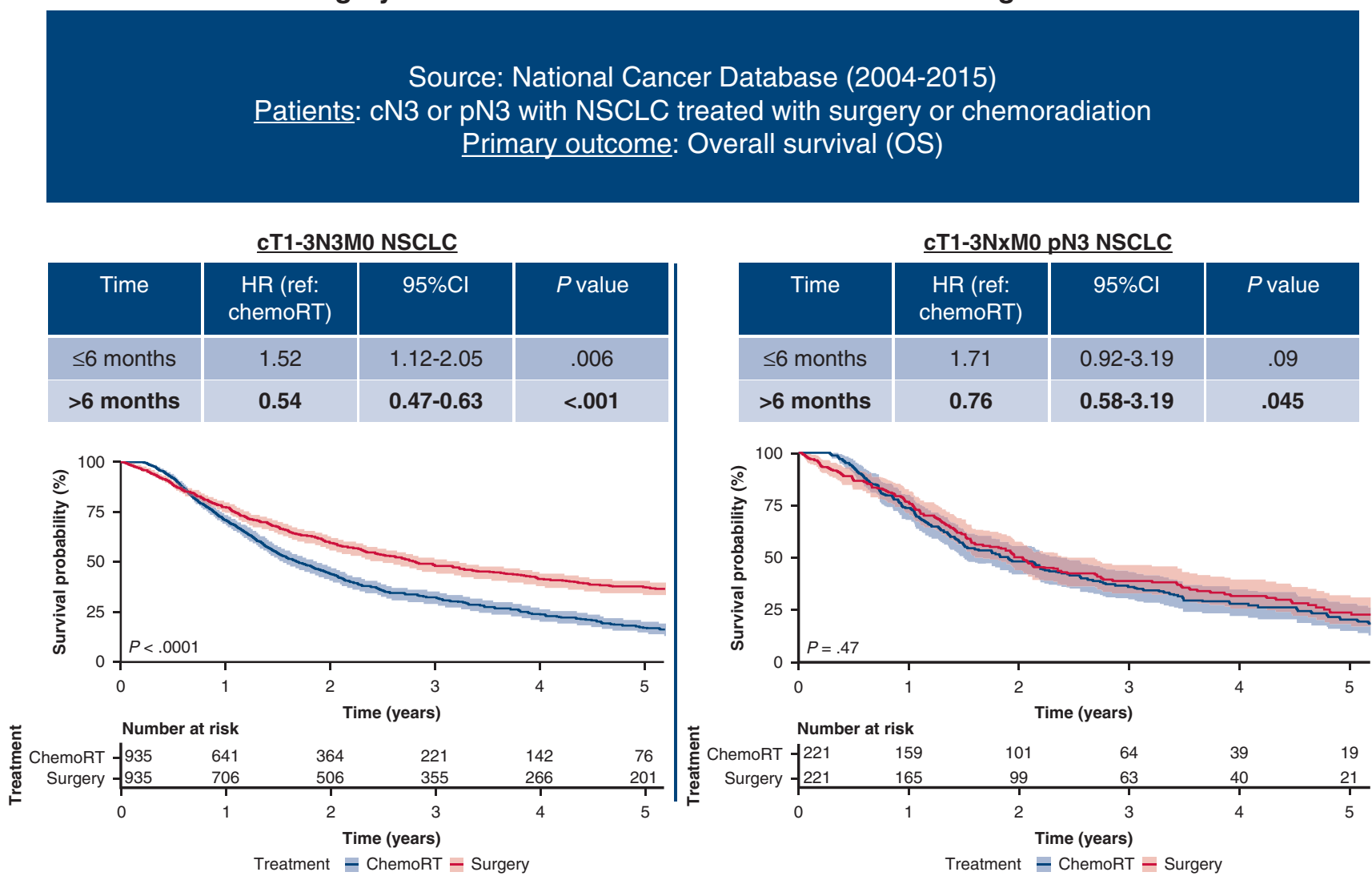

In both cN3 and pN3 NSCLC, surgery is associated with improved long-term survival compared to chemoradiation; randomized trials are needed to examine the role of surgery in N3 NSCLC

FIGURE 5. In this National Cancer Database study, surgery was associated with improved long-term overall survival compared with chemoradiation in patients with clinical or pathologic N3 disease. This graphical abstract demonstrates the results of propensity score matched-analysis of clinical and pathologic N3 disease patients with hazard ratios and confidence intervals from time-varying multivariable Cox regression presented in tables and Kaplan-Meier survival curves with numbers at risk. NSCLC, Non-small cell lung cancer; $H R$, hazard ratio; $C I$, confidence interval.

of a margin-negative resection may experience a greater survival benefit. Additionally, our time-varying Cox models suggest that patients who are good candidates for surgery and therefore survive beyond the initial few months following surgery are also more likely to benefit from resection. In our institution, surgery is rarely offered for patients with N3 disease. Surgery is offered to patients who exhibit a significant radiographic response to neoadjuvant therapy, who do not have supraclavicular disease, who are good surgical candidates, and who have nonbulky nodal disease.

Our study has several limitations in addition to those already described. As a retrospective cohort study, there is inherent selection bias for which we cannot accommodate. For instance, patients offered surgery rather than chemoradiation for N3 disease likely had nonbulky, single, or oligostation nodal involvement and a good response to induction therapy, if offered. However, none of these variables nor specific N3 disease location are coded in the NCDB. We did attempt to define this selection bias with a subgroup analysis of $\mathrm{cN} 3$ patients undergoing surgery following induction therapy, as discussed above. The NCDB also does not contain information about staging and restaging techniques used. For instance, although we draw inferences about invasive nodal staging from the pathologic nodal stage reported for patients who did not receive a resection, the NCDB does not explicitly catalog invasive nodal staging. Patients offered chemoradiation treatment may also have been poor surgical candidates and consequently experienced worse survival. However, we attempted to adjust for such confounding by excluding chemoradiation patients who were not offered surgery due to poor fitness, as coded in the database, and by using propensity score matching based on variables like age, comorbidity index, treatment at an academic center, and tumor size. Finally, this study period predates that of the Phase III, Randomised, Double-blind, Placebo-controlled, Multi-centre, International Study of MEDI4736 as Sequential Therapy in Patients with Locally Advanced, Unresectable non-Small 
Cell Lung Cancer (Stage III) Who Have not Progressed Following Definitive, Platinum-based, Concurrent Chemoradiation Therapy (PACIFIC) trial, ${ }^{24,25}$ and as a result, we cannot compare the outcomes of patients receiving surgery with those receiving chemoradiation followed by durvalumab. However, the PACIFIC trial also did not report subgroup analyses on patients with $\mathrm{N} 3$ disease, and reported an overall median time to death or distant metastasis of 28 months in the treatment arm, which is comparable to the median survival of 35 months observed in surgery patients with cN3 disease in our study. ${ }^{24}$ The PACIFIC study also does not contain information on how patients were deemed unresectable, which further limits its interpretation. Future research should focus on the potentially complementary effects of surgery and checkpoint inhibition in multimodal treatment of N3 lung cancer.

\section{CONCLUSIONS}

We report the most comprehensive analysis of outcomes following surgery versus chemoradiation in patients with N3 NSCLC, finding that although early survival was similar between the groups, surgery was associated with improved long-term survival compared with chemoradiation in patients with $\mathrm{cN} 3$ or pN3 lung cancer (Figure 5). In a selected group of patients with N3 NSCLC, surgery may offer superior survival and can be considered as part of multimodal therapy, although prospective, randomized controlled trials are needed to evaluate the role of surgery in multimodal therapy for this patient population.

\section{Webcast}

You can watch a Webcast of this AATS meeting presentation by going to: https://aats.blob.core.windows.net/media/ 19\%20AM/Monday_May6/201DF/201DF/S84\%20-\%20 Locally\%20advanced\%20lung\%20cancer/S84_6_webcast_ 031409114.mp4.

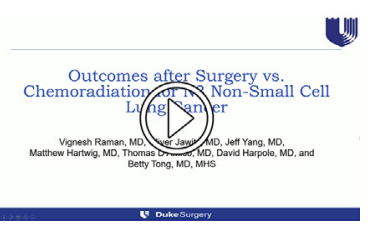

\section{Conflict of Interest Statement}

Authors have nothing to disclose with regard to commercial support.

The American College of Surgeons is in a Business Associate Agreement that includes a data use agreement with each of its Commission on Cancer-accredited hospitals. The data used in the study are derived from a de-identified National Cancer Database file. The American College of Surgeons and the Commission on Cancer have not verified and are not responsible for the analytic or statistical methodology used or the conclusions drawn from these data by the investigators.

\section{References}

1. European Society of Medical Oncology Clinical practice guidelines: early and locally advanced non-small cell lung cancer. Available at: https://www.esmo. org/content/download/129682/2437285/file/Clinical-Practice-Guidelines-SlidesetEarly-and-Locally-Advanced-Non-Small-Cell-Lung-Cancer-NSCLC.pdf. Accessed March 19, 2019.

2. National Comprehensive Cancer Network. National Comprehensive Cancer Network (NCCN) guidelines on treatment of small cell lung cancer. 2018. Available at: https://www.nccn.org/professionals/physician_gls/PDF/nscl.pdf. Accessed June 30, 2019.

3. DeCamp MM, Rice TW, Adelstein DJ, Chidel MA, Rybicki LA, Murthy SC, et al. Value of accelerated multimodality therapy in stage IIIA and IIIB nonsmall cell lung cancer. J Thorac Cardiovasc Surg. 2003;126:17-25.

4. Ichinose Y, Fukuyama Y, Asoh H, Ushijima C, Okamoto T, Ikeda J, et al. Induction chemoradiotherapy and surgical resection for selected stage IIIB non-smallcell lung cancer. Ann Thorac Surg. 2003;76:1810-4.

5. Stupp R, Mayer M, Kann R, Weder W, Zouhair A, Betticher DC, et al. Neoadjuvant chemotherapy and radiotherapy followed by surgery in selected patients with stage IIIB non-small-cell lung cancer: a multicentre phase II trial. Lancet Oncol. 2009;10:785-93.

6. Grunenwald DH, André F, Le Péchoux C, Girard P, Lamer C, Laplanche A, et al. Benefit of surgery after chemoradiotherapy in stage IIIB (T4 and/or N3) nonsmall cell lung cancer. J Thorac Cardiovasc Surg. 2001;122:796-802.

7. Stamatis G, Eberhardt W, Stüben G, Bildat S, Dahler O, Hillejan L. Preoperative chemoradiotherapy and surgery for selected non-small cell lung cancer IIIB subgroups: long-term results. Ann Thorac Surg. 1999;68:1144-9.

8. Weiden PL, Piantadosi S. Preoperative chemotherapy (cisplatin and fluorouracil) and radiation therapy in stage III non-small cell lung cancer. A phase 2 study of the LCSG. Chest. 1994;106(6 Suppl):344S-7S.

9. Pitz CCM, Maas KW, Swieten HAV, Rivière AB de la, Hofman P, Schramel FMNH. Surgery as part of combined modality treatment in stage IIIB non-small cell lung cancer. Ann Thorac Surg. 2002;74:164-9.

10. Albain KS, Crowley JJ, Turrisi AT III, Gandara DR, Farrar WB, Clark JI, et al. Concurrent cisplatin, etoposide, and chest radiotherapy in pathologic stage IIIB non-small-cell lung cancer: a Southwest Oncology Group Phase II Study, SWOG 9019. J Clin Oncol. 2002;20:3454-60.

11. Rusch VW, Albain KS, Crowley JJ, Rice TW, Lonchyna V, McKenna R Jr, et al. Surgical resection of stage IIIA and stage IIIB non-small-cell lung cancer after concurrent induction chemoradiotherapy. A Southwest Oncology Group trial. J Thorac Cardiovasc Surg. 1993;105:97-104.

12. Albain KS, Swann RS, Rusch VW, Turrisi AT III, Shepherd FA, Smith C, et al. Radiotherapy plus chemotherapy with or without surgical resection for stage III non-small-cell lung cancer: a phase III randomised controlled trial. Lancet. 2009; 374:379-86.

13. Bott MJ, Patel AP, Crabtree TD, Morgensztern D, Robinson CG, Colditz GA, et al. Role for surgical resection in the multidisciplinary treatment of stage IIIB non-small cell lung cancer. Ann Thorac Surg. 2015;99:1921-8.

14. Galetta D, Cesario A, Margaritora S, Porziella V, Macis G, D'Angelillo RM, et al. Enduring challenge in the treatment of nonsmall cell lung cancer with clinical stage IIIB: results of a trimodality approach. Ann Thorac Surg. 2003;76:1802-9.

15. Takeda S. Results of pulmonary resection following neoadjuvant therapy for locally advanced (IIIA-IIIB) lung cancer. Eur J Cardiothorac Surg. 2006;30:184-9.

16. Bilimoria KY, Stewart AK, Winchester DP, Ko CY. The National Cancer Data Base: a powerful initiative to improve cancer care in the United States. Ann Surg Oncol. 2008; 15:683-90.

17. MatchIt: nonparametric preprocessing for parametric causal inference. Available at: https://gking.harvard.edu/matchit. Accessed April 18, 2019.

18. Austin PC. Balance diagnostics for comparing the distribution of baseline covariates between treatment groups in propensity-score matched samples. Stat Med. 2009;28:3083-107.

19. Harrell FE. Multivariable modeling strategies. In: Harrell Frank E Jr., ed. Regression Modeling Strategies: With Applications to Linear Models, Logistic and Ordinal Regression, and Survival Analysis. New York: Springer International Publishing; 2015.

20. Li H, Han D, Hou Y, Chen H, Chen Z. Statistical inference methods for two crossing survival curves: a comparison of methods. PLOS ONE. 2015;10: e0116774. 
21. Albain KS, Rusch VW, Crowley JJ, Rice TW, Turrisi AT III, Weick JK, et al. Concurrent cisplatin/etoposide plus chest radiotherapy followed by surgery for stages IIIA (N2) and IIIB non-small-cell lung cancer: mature results of Southwest Oncology Group phase II study 8805. J Clin Oncol. 1995;13:1880-92.

22. Krantz SB, Howington JA, Wood DE, Kim KW, Kosinski AS, Cox ML, et al. Invasive mediastinal staging for lung cancer by the Society of Thoracic Surgeons Database participants. Ann Thorac Surg. 2018;106:1055-62.

23. Thornblade LW, Wood DE, Mulligan MS, Farivar AS, Hubka M, Costas KE, et al. Variability in invasive mediastinal staging for lung cancer: a multicenter regional study. J Thorac Cardiovasc Surg. 2018;155:2658-26571.e1.

24. Antonia SJ, Villegas A, Daniel D, Vicente D, Murakami S, Hui R, et al. Overall survival with durvalumab after chemoradiotherapy in stage III NSCLC. $N$ Engl J Med. 2018;379:2342-50.

25. Antonia SJ, Villegas A, Daniel D, Vicente D, Murakami S, Hui R, et al. Durvalumab after chemoradiotherapy in stage III non-small-cell lung cancer. $N$ Engl $J$ Med. 2017;377:1919-29.

Key Words: non-small cell lung cancer, N3, locally advanced, surgery, multimodal therapy

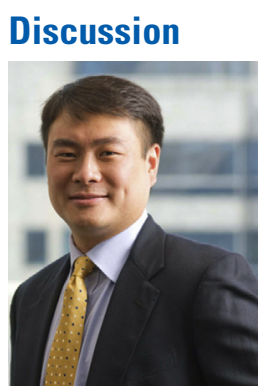

Dr James Huang (New York, NY). Thanks for the opportunity to discuss this paper and thank you, Dr Raman, for a nicely presented talk and for sending me the manuscript in advance.

Dr Raman and colleagues have examined the issue of surgery for N3 lung cancer by performing a retrospective analysis of the available data in the National Cancer Database (NCDB), and they conclude that surgery should be considered for selected patients with stage N3 disease. The authors acknowledge that surgery is generally not recommended for stage N3 disease, the National Comprehensive Cancer Center guidelines do not offer an option for surgery for N3 disease, so I think we need to be a little careful about drawing any conclusions that are potentially practice changing from a retrospective observational study. As you know, all retrospective studies are, by definition, hypothesis-generating, and really hypothesis-generating only. So I submit that the real conclusion that you should arrive at is whether or not this question is worthy of further prospective study. A safer conclusion might be that a clinical trial exploring the value of surgery for N3 disease is warranted.

In your analysis, only $21 \%$ of the clinical stage N3 patients underwent induction therapy, and you surmise that these patients were downstaged. But I think for clarity's sake what we are really trying to say is that these patients really did not have N3 disease at all. That could explain the survival differences that you see, that most of the surgical patients actually turned out to be stage I or stage II in reality. So I would say another conclusion that you might take away from this analysis might simply be that clinical staging of nodal status is highly inaccurate, or at least in the NCDB.
I have a couple of questions, which I will ask one at a time. Given that surgery is not recommended for N3 disease, do you have a better sense of who exactly these patients are that got operated on?

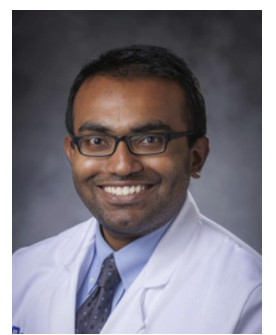

Dr Vignesh Raman (Durham, NC). I think there are 2 lessons that we can glean from this study. One, like you mentioned, only $21 \%$ of patients received induction therapy with clinical stage N3 disease. They could also represent patients who based on their pathologic nodal stage responded very well to induction therapy, because we do not have any restaging information from NCDB. So patients with a good to complete response to induction therapy might have been the ones who were ultimately offered surgery; $87 \%$ of them were downstaged, as explained.

The second, looking at our time varying Cox models, is that the survival benefit is best for patients beyond the immediate postoperative stage of 7.5 months. So patients who are excellent surgical candidates are probably the ones who benefit most from surgery in this situation.

And I think those are at least 2 specific characteristics that we can infer from the study.

Dr Huang. And clearly selection bias is at play here, and you state that surgery should be offered for selected patients. So can you help guide us as to which patients to select?

Dr Raman. Based on the study, we could argue that patients with limited resectable clinical stage N3 disease who had a good response to induction therapy and who are good surgical candidates might be considered. The reason I add the clause of resectable N3 disease is that we noticed the sort of complete resection rate for patients with $\mathrm{N} 3$ disease is $73 \%$ to $80 \%$, whether we are looking at clinical or pathologic stage, which is a very high complete resection rate, suggesting that patients who were selected for surgery probably had a pretest probability of resectability.

Dr Huang. In terms of complete resection of N3 disease, how do we resect the N3 disease?

Dr Raman. Unfortunately, there is no information about nodal stations in the NCDB, so it's unclear if these were patients who had an isolated supraclavicular node that was then excisionally biopsied or whether these patients had an isolated node initially in the contralateral mediastinum or hilum that was sterilized by induction therapy.

Dr Huang. And finally, as you have pointed out and as Dr Pass nicely presented earlier, the Phase III, Randomised, Double-blind, Placebo-controlled, Multi-centre, International Study of MEDI4736 as Sequential Therapy in Patients with Locally Advanced, Unresectable non-Small Cell Lung Cancer (Stage III) Who Have not Progressed Following Definitive, Platinum-based, Concurrent 
Chemoradiation Therapy trial has really changed practice and immunotherapy is here to stay. So in light of that, how should we interpret your results here?

Dr Raman. I think 2 limitations specific to the study that Dr Pass also mentioned in his talk were that we don't know on what basis patients were deemed unresectable, and we don't know what subset of patients with stage IIIB disease had N3 rather than T4 N2 involvement. In that context, you could argue that our results suggest that at least some patients with $\mathrm{N} 3$ disease might benefit from enrollment in a future prospective clinical trial examining the role of durvalumab in a perioperative setting.

Dr Huang. Thank you. Congratulations.

Dr Henning Gaissert (Boston, Mass). You made a statement about complete resection. How do you do that in N3 disease and how do you confirm that in your patients?

Dr Raman. For the NCDB, the independent tumor registrars look at the surgical pathology reports, and based on that, if there is no margin involvement, code it as an R0 resection. Because there is no station information available, we don't know if these patients had remnant nodal disease: if they had, for instance, an isolated supraclavicular node that was excisionally biopsied and subsequently no other evidence of $\mathrm{N} 3$ disease or if these patients initially pre- sented with a contralateral mediastinal hilar node that was then sterilized by induction therapy. Unfortunately, we do not have the granularity of the NCDB to answer that question specifically and accurately.

Dr Gaissert. I submit R0 resections don't exist in N3 disease.

Dr Raman. Point taken.

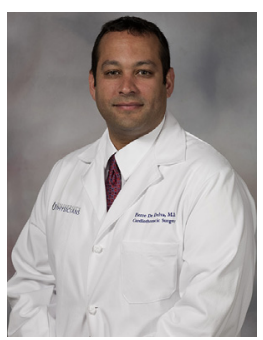

Dr Pierre de Delva (Jackson, Miss). I was surprised by the $9 \%$ incidence of operations for N3 disease. Is it possible that a good number of those patients were patients who went to the operating room with a clinical stage N3 diagnosis, had invasive staging proven not to be $\mathrm{N} 3$ disease and go

on to surgery?

Dr Raman. That is entirely possible, which is why we did the subgroup analysis in those with induction therapy and with proven pathologic N3 disease.

Dr Gaissert. I want to know if it's single-station N3 or not single-station N3.

Dr Raman. Unfortunately, a limitation of the NCDB is that there is no station information provided, so we don't know the identity, number, or bulk of involved nodes. 
TABLE E1. Background characteristics of patients with clinical stage N3 non-small cell lung cancer grouped by treatment

\begin{tabular}{|c|c|c|c|}
\hline Characteristic & $\begin{array}{l}\text { Chemoradiation } \\
\quad(\mathbf{n}=\mathbf{5 2 2 7})\end{array}$ & $\begin{array}{c}\text { Surgery } \\
(\mathrm{n}=\mathbf{1 1 7 3})\end{array}$ & $P$ value \\
\hline Age (y) & $66(58-72)$ & $66(58-73)$ & .24 \\
\hline Female sex & $2381(46)$ & $510(44)$ & .21 \\
\hline $\begin{array}{l}\text { Race } \\
\text { White } \\
\text { Black } \\
\text { Other }\end{array}$ & $\begin{array}{l}4384(84) \\
628(12) \\
180(4)\end{array}$ & $\begin{array}{r}1007(86) \\
123(11) \\
38(3)\end{array}$ & .29 \\
\hline Year of diagnosis & $2011(2008-2013)$ & $2010(2007-2012)$ & $<.001$ \\
\hline $\begin{array}{l}\text { Charleson-Deyo comorbidity condition score } \\
0 \\
1 \\
2+\end{array}$ & $\begin{array}{c}3565(68) \\
1201(23) \\
461(9)\end{array}$ & $\begin{array}{l}675(58) \\
346(30) \\
152(13)\end{array}$ & $<.001$ \\
\hline $\begin{array}{l}\text { Insurance status } \\
\text { Private } \\
\text { Government } \\
\text { None }\end{array}$ & $\begin{array}{c}1799(35) \\
3180(62) \\
154(3)\end{array}$ & $\begin{array}{c}423(37) \\
691(60) \\
37(3)\end{array}$ & .48 \\
\hline $\begin{array}{l}\text { Facility location } \\
\text { Metro } \\
\text { Urban } \\
\text { Rural }\end{array}$ & $\begin{array}{l}4044(77) \\
853(16) \\
330(6)\end{array}$ & $\begin{array}{l}905(77) \\
205(18) \\
63(5)\end{array}$ & .34 \\
\hline Academic center & $1805(35)$ & $442(38)$ & .05 \\
\hline $\begin{array}{l}\text { Type of surgery } \\
\text { Wedge resection } \\
\text { Segmentectomy } \\
\text { Lobectomy } \\
\text { Pneumonectomy }\end{array}$ & N/A & $\begin{array}{c}185(16) \\
28(2) \\
609(52) \\
75(6)\end{array}$ & N/A \\
\hline Nodes examined & N/A & $7(2-17)$ & N/A \\
\hline Tumor size $(\mathrm{mm})$ & $35(23-49)$ & $30(20-45)$ & $<.001$ \\
\hline $\begin{array}{l}\text { Histology } \\
\text { Adenocarcinoma } \\
\text { Squamous cell carcinoma } \\
\text { Other }\end{array}$ & $\begin{array}{c}2344(57) \\
1546(37) \\
251(6)\end{array}$ & $\begin{array}{l}536(48) \\
170(15) \\
407(37)\end{array}$ & $<.001$ \\
\hline $\begin{array}{l}\text { Perioperative chemotherapy } \\
\text { Neoadjuvant } \\
\text { Adjuvant } \\
\text { None }\end{array}$ & N/A & $\begin{array}{l}209(18) \\
407(35) \\
536(47)\end{array}$ & N/A \\
\hline Complete resection rate & N/A & $844(80)$ & N/A \\
\hline 30-d mortality & N/A & $39(4)$ & N/A \\
\hline 90-d mortality & N/A & $81(8)$ & N/A \\
\hline Radiation treatment volume (Gy) & $64.8(60.0-68.4)$ & $0(0-50.4)$ & $<.001$ \\
\hline
\end{tabular}

Values are presented as median (interquartile range) or $\mathrm{n}(\%) . N / \mathrm{A}$, not available. 
TABLE E2. Background characteristics of patients with pathologic stage N3 non-small cell lung cancer grouped by treatment

\begin{tabular}{|c|c|c|c|}
\hline Characteristic & $\begin{array}{l}\text { Chemoradiation } \\
\qquad(\mathrm{n}=\mathbf{5 1 5})\end{array}$ & $\begin{array}{l}\text { Surgery } \\
(\mathrm{n}=\mathbf{2 8 3})\end{array}$ & $P$ value \\
\hline Age (y) & $65(57-72)$ & $65(57-71)$ & .86 \\
\hline Female sex & $251(49)$ & $132(47)$ & .62 \\
\hline $\begin{array}{l}\text { Race } \\
\text { White } \\
\text { Black } \\
\text { Other }\end{array}$ & $\begin{array}{c}444(87) \\
48(9) \\
21(4)\end{array}$ & $\begin{array}{r}241(85) \\
31(11) \\
11(4)\end{array}$ & .77 \\
\hline Year of diagnosis & $2010(2008-2012)$ & 2009 (2007-2012) & .002 \\
\hline $\begin{array}{l}\text { Charleson-Deyo comorbidity condition score } \\
0 \\
1 \\
2+\end{array}$ & $\begin{array}{c}356(69) \\
120(23) \\
39(8)\end{array}$ & $\begin{array}{r}174(62) \\
81(29) \\
28(10)\end{array}$ & .09 \\
\hline $\begin{array}{l}\text { Insurance status } \\
\text { Private } \\
\text { Government } \\
\text { None }\end{array}$ & $\begin{array}{c}183(36) \\
312(61) \\
13(3)\end{array}$ & $\begin{array}{c}109(29) \\
159(57) \\
11(4)\end{array}$ & .34 \\
\hline $\begin{array}{l}\text { Facility location } \\
\text { Metro } \\
\text { Urban } \\
\text { Rural }\end{array}$ & $\begin{array}{c}396(77) \\
83(16) \\
36(7)\end{array}$ & $\begin{array}{r}230(81) \\
40(14) \\
13(5)\end{array}$ & $<.001$ \\
\hline Academic center & $230(45)$ & $111(39)$ & .16 \\
\hline $\begin{array}{l}\text { Type of surgery } \\
\text { Wedge resection } \\
\text { Segmentectomy } \\
\text { Lobectomy } \\
\text { Pneumonectomy }\end{array}$ & N/A & $\begin{aligned} 63 & (22) \\
7 & (3) \\
128 & (45) \\
21 & (7)\end{aligned}$ & N/A \\
\hline Nodes examined & N/A & $7(3-19)$ & N/A \\
\hline Tumor size $(\mathrm{mm})$ & $29(19-42)$ & $29(19-40)$ & \\
\hline $\begin{array}{l}\text { Histology } \\
\text { Adenocarcinoma } \\
\text { Squamous cell carcinoma } \\
\text { Other }\end{array}$ & $\begin{array}{c}274(66) \\
118(28) \\
23(6)\end{array}$ & $\begin{array}{r}151(61) \\
57(23) \\
41(17)\end{array}$ & $<.001$ \\
\hline $\begin{array}{l}\text { Perioperative chemotherapy } \\
\text { Neoadjuvant } \\
\text { Adjuvant } \\
\text { None }\end{array}$ & N/A & $\begin{array}{r}31(11) \\
153(55) \\
96(34)\end{array}$ & N/A \\
\hline Complete resection rate & N/A & $190(73)$ & N/A \\
\hline 30-d mortality & N/A & $13(5)$ & N/A \\
\hline 90-d mortality & N/A & $24(9)$ & N/A \\
\hline Radiation treatment volume ( $\mathrm{Gy}$ ) & $66(61-70)$ & $40(0-54)$ & $<.001$ \\
\hline
\end{tabular}

Values are presented as median (interquartile range) or $\mathrm{n}(\%) . N / A$, not available. 